\title{
Transition from Conventional to Organic Farming Systems: II. Summary of Discussion Session and Recommendations for Future
} Research

\author{
Gladis M. Zinati
}

Additional Index wOrds. cover crops, mulches, noxious weeds, nutrient minerals, pest management tactics, pretransition period, site-specific, weed dormancy, weed seed banks

\begin{abstract}
Summary. A question/answer discussion session was conducted at the conclusion of the workshop "Pest Management During Transition to Organic Farming Systems". The following categories were used to summarize the discussion: 1) questions and answers related to cultural and biological practices and their effects under various climatic conditions, 2) recommendations for pest management, and 3) future research needs. While many tactics are available, selecting and adopting the most suitable approach depends on soil conditions of the land, location, and the availability of the resources at affordable prices. Definitely, more research studies are needed on 1) weed seed banks under various cultural practices at different regions, 2) relationships between soil nutrients, and pest control, and 3) approaches to increase profitability of organic production during the transition period.
\end{abstract}

I $\mathrm{n}$ this paper, the discussion that followed the presentations in the workshop Pest Management During Transition to Organic Farming Systems is summarized. The discussion was an interaction between the audience and the speakers and focused on different concepts, strategies and recommendations for studies on pest management during transition to organic farming. The following, in a question and answer format, captures aspects of this conversation between speakers and audience with supportive references.

Do We NeEd a PRETRANSITION PERIOd befORE the tRANSITION PERIOD FOR CONTROLLING SOME NOXIOUS PESTS? Transition or conversion period to organic farming is a period when synthetic fertilizers and chemical pesticides are not applied during crop production. This is a 3-year period before certification is granted for organic crop production (U.S. Department of Agriculture, 1990).

However, many noxious weeds and nematodes may require more time to reduce their population densities before the land can be certified for organic production. Under such conditions, a pretransition period is necessary to attain acceptable levels of pests that can be tolerated without synthetic pesticides. A gradual rather than an abrupt pretransition is suggested as a good approach, a period during which a hybrid system is followed.

Research associate, Department of Environmental Horticulture, 1533 Fifield Hall, Gainesville, FL 3261 1; email gmz@mail.ifas.ufl.edu. This work was supported by the Florida Agricultural Experiment Station and approved for publication as journal series R-08568. The author is grateful for Dennis McConnell for his review of the manuscript and instructive criticism. 
This system may incorporate a combination of cultural and biological approaches with chemical pest management until the system gradually becomes suitable to start the synthetic fertilizer- and chemical-free transition period. For example, in sunny warm regions, such as Florida, growers may substitute the use of soil fumigants (such as methyl bromide) with solarization or use cover crops to suppress soil pest levels while using synthetic fertilizers to ensure high crop yields. These non-synthetic chemical approaches may become part of pest management before growers switch from conventional to organic farming.

MANY PEST MANAGEMENT tACTICS WERE PRESENTED IN THIS WORKSHOP. HOW DO WE SELECT THE RIGHT TACTIC FOR PEST MANAGEMENT? Farm location and size, history of the land, and more importantly, availability of resources play a major role in selecting any or all of the discussed tactics. For example, marigold (Tagetes patula) has been found to effectively suppress soil nematodes (McSorley et al., 1999) but its use is costly. Incorporation of marigolds in a cover cropping system may be feasible and economically justified on small land plots and not on large plots. Also, a grower may depend on hand weeding where hand labor is available and inexpensive rather than on cultivation or mowing for weed control.

What WAS THE TYPE OF MULCH THAT WAS USED FOR SUPPRESSING ROOT rot (Phytophthora cinnamomi ) in AVOCADO ORCHARDS, AND HOW LONG WOULD IT TAKE TO SEE THE BENEFITS OF AN ORGaNIC MULCh? Fresh organic (commercial yard waste) mulch was applied around the young avocado (Persea americana) trees to suppress Phytophthoracinnamomilevels (Downer et al., 200 la, 2001b). Reaping the benefits of using organic mulches to control soil diseases may take two to three years. In the first year, growers may experience a significant increase in disease problems. This may be attributed to the increase in moisture content that accompanies mulch application. However, as the mulch biomass decreases $(66 \%$ in the first year) more cellulase enzymes will be produced due to the increase in the microbial activity. A 6-inch-thick $(15-\mathrm{cm})$ layer of this mulch is considered a good barrier for weeds and for disease suppression in avocado orchards.

WhAT IS A SUITABLE PERCENT FOR COVER CROP MIXTURES? Studies show that climate and location of the site are important factors when making a decision on the percent of cover crop mixtures. For example, it was found that a ratio of 40:60 for cowpea (Vigna sinensis) and sorghum grass (Sorghum sudanese $\mathrm{x}$ $S$. bicolor), respectively, worked best in North Carolina. However, a ratio of 33:67 was better for warm cloud-free desert conditions of California. Therefore, the selections of appropriate mixes cannot be generalized from one region to another.

Does the use of cover crops AFFECT THE WEED SEED BANK? Utilization of cover crops such as cowpeas and sorghum-Sudan and may increase the microbial biomass and reduce the weed population. However, more studies are needed on the effects of cover crop, mulches and soil temperatures on weed seed banks, weed dormancy and suppression of weed seed germination.

MANY GROWERS PRODUCING CROPS ORGANICALLY BELIEVE THAT CATION BALANCING IS RELATED TO WEED POPULATION. Could gYpsum be USED IN CERTIFIED ORGANIC FARMING AND IS THERE ANY CATION BALANCING RELATIONSHIP WITH WEED POPULATION? Many organic farming growers believe in and utilize Albrecht's formula also called base saturation ratio (Albrecht, 1975). Growers apply high calcium limestone or gypsum (calcium sulfate) to add $\mathrm{Ca}$ and displace excess soil Mg and $\mathrm{K}$ (Cantisano, 1992; Kinsey and Walters, 1993). There are claims that this practice may increase crop resistance to pests, reduce weeds, and increase marketable yields but these claims lack valid evidence (Schonbeck, 2000). Cation imbalances have been claimed to inhibit beneficial soil organisms (Kinsey and Walters, 1993) but little research has been conducted on effects of base saturation ratio on soil life. On the other hand, research by Ingham (E. Ingham, unpublished data) demonstrated the vital role of soil organisms in providing $\mathrm{N}, \mathrm{P}, \mathrm{K}, \mathrm{Ca}$, and other nutrients. Gypsum and wallboard slabs can be used as amendments. There are a few research findings that show correlations between nutrients and weeds, but results were not consistent from farm to farm. Gypsum applications may be appropriate to correct Ca deficiency and aluminum excess of a highly acid soil $(\mathrm{pH}<5.0)$ that restricts crop root growth. However, gypsum should be used with caution especially on sandy soils where gypsum may cause excessive leaching of $\mathrm{K}$ and $\mathrm{Mg}$.
How Can a transition Period be PROFITABLE? Crop production profitability during a transition period, may be increased by including in the crop and pest management plan a pretransition period to reduce pest populations to a minimum, improve soil quality, and select a high value crop. An example is baby salad mix, which can be sold at high price. In some regions, climate may permit planting three to four crops per year.

\section{Conclusions}

A pretransition period is recommended to phase out conventional pest management practices. This approach will reduce yield losses due to pests, reduce pest pressure and provides growers with an opportunity to excel in the integration of pest management practices.

Site location, climate and soil conditions of the land are important factors in designing and selecting the types of organic amendments, ratios and application methods for pest control upon switching to organic farming from conventional farming.

More research studies are needed to: 1 ) evaluate effects of nutrient minerals, soil temperature, light and cover crops on weed seed banks, weed dormancy, disease control and crop yields, and 2) find ways to increase crop production profitability during, and after the transition period.

\section{Literature cited}

Albrecht, W.A. 1975. Soil fertility and animal health. In: C. Walters, Jr. (ed.). The Albrecht papers. vol. 2. Acres USA, Kansas City, Mo.

Cantisano, A. 1992. Know your soil: A handbook for understanding your soil report. Org. Agr. Adv., Colfax, Calif.

Downer, A.J., J.A. Menge, and E. Pond. 2001a. Effects of cellulytic enzymes on Phytophthora cinnamoni Rands. Phytopathology 91:839-846.

Downer, A.J., J.A. Menge, and E. Pond. 2001b. Association of cellulytic enzyme activities in eucalyptus mulches with biological control of Phytophora cinnamomi Rands. Phytopathology 91:847-855.

Kinsey, N. and C. Walters. 1993. Neal Kinsey's handson agronomy. Acres USA, Kansas City, Mo.

McSorley, R., M. Ozores-Hampton, P.A. Stansly, and J.M. Conner. 1999. Nematode management, soil fertility and yield in organic vegetable production. Nematropica 29:205-213.

Schonbeck, M. 2000. Soil nutrient balancing in sustain able vegetable production. Final Rpt. No. 99-05 submitted to Organic Farming Res. Found., Santa Cruz, Calif.

U.S. Department of Agriculture. 1990. Federal organic foods production act of 1990. Agr. Mktg. Serv. Natl. Organic Prog., Wash., D.C. 7 Jan. 2002. <http:// www.ams.usda.gov/nop/orgact.htm> 